\title{
Piero Gleijeses
}

Visions of Freedom: Havana, Washington, Pretoria, and the Struggle for Southern

Africa, 1976-1991. Chapel Hill: University of North Carolina Press, 2013. xiv + 655 pp.

(Cloth US\$40.0o)

\section{Christine Hatzky}

Cubans in Angola: South-South Cooperation and Transfer of Knowledge, 1976-1991.

Madison: University of Wisconsin Press, 2015. xvi + 386 pp. (Paper US\$ 39.95)

Fidel Castro characterized the Cuban intervention in Angola as "the most beautiful cause." Between 1975 and 1991, 337,00o Cuban soldiers and 43,00o Cuban civilians served in Angola. The Cuban intervention bolstered the political and military power of the revolutionary group, Movimento Popular de Libertação de Angola (MPLA) under the leadership of, first, Agostinho Neto (1975-79) and then José Eduardo dos Santos (1979-). With the critical assistance of Cuban troops, the MPLA gained control over the capital city, Luanda, and the oil-producing enclave of Cabinda. The MPLA fought its Western-backed rival, União Nacional para a Independência Total de Angola (UNITA), led by Jonas Savimbi, to a standstill, although it would take another decade of civil war before the MPLA would finally defeat UNITA in 2002. Cuban military forces also joined with the MPLA in repelling from Angola the South African forces of the apartheid regime in Pretoria. The Cuban-Angolan victory in the 1988 battle of Cuito Cuanavale proved a momentous international event. In the wake of defeat, South Africa agreed to honor U.N. Resolution 435 (1978) and grant independence to Namibia. South Africa had controlled Namibia, which it called South West Africa, since the end of World War I. With Angola and Namibia's independence secured, Cuba withdrew its soldiers and educators from Angola in 1991. Among Cuban political and military elites, the Cuban adventure in Angola continues to be judged a glorious victory and a validation of the Cuban Revolution. The island nation had carried out its internationalist duty in fighting for independence and revolution.

Piero Gleijeses and Christine Hatzky have addressed the question of how to analyze the Cuban mission in Angola in ways that are both similar and dissimilar. Both have conducted prodigious historical research that is multiarchival and multilingual. Gleijeses, a professor of American foreign policy at the Johns Hopkins School of Advanced International Studies, has worked in archives in 12 countries and read newspapers from 17 countries. Each year, he spends two months in Havana. Befriended by Jorge Risquet Valdés, who served as Castro's point man in Angola, he collected 15,000 Cuban documents. He also took advantage of South Africa's recent decision to open its archives. Gleijeses

(C) STEPHEN G. RABE, 2017 | DOI: 10.1163/22134360-09101018

This is an open access article distributed under the terms of the Creative Commons 
read Afrikaans books and documents and interviewed 150 Angolans, Cubans, Namibians, South Africans, and U.S. officials. Hatzky, a professor at the Leibniz Universität Hannover who carried out research in Angola, Cuba, Portugal, and the United States, found critical documents on Angola's educational system in a cellar. Her book includes a photo of her working in these "dead archives" wearing a surgical mask to protect her health! Hatzky also interviewed 139 Angolans and Cubans. Neither Gleijeses nor Hatzky scored an interview with the big prize - Fidel Castro.

The two focused on different subjects and arrived at different assessments of the Cuban role in Angola. Gleijeses analyzed the activities of Cuban soldiers, and describes in minute detail the battles they fought. Taking a traditional approach to diplomatic history, he also recounts the political and diplomatic maneuvers of the key national actors in the struggle for Cold War supremacy in southern Africa-Cuba, South Africa, the Soviet Union, and the United States. Cuba's struggle proved costly, with more than 2,100 military casualties. But Gleijeses is persuaded that the Cuban military intervention saved Angola, helped free Namibia, and set the stage for the release of Nelson Mandela from jail in 1990 and the end of apartheid in South Africa. "I do not know of any other country, in modern times, for which idealism has been such a key component of its foreign policy as for Castro's Cuba" (p. 526). Hatzky, on the other hand, explores the activities of Cuban civilians in Angola, especially the 8,00o who served as educators, drawing conclusions about them that are far less positive than those of Gleijeses. Although Hatzky does not use the term, a reader of her book could readily decide that Cubans practiced "cultural imperialism" in Angola.

Visions of Freedom can be seen as a sequel to Gleijeses's prize-winning Conflicting Missions: Havana, Washington, and Africa, 1959-1976 (2002), which provided startling information. Prior to the massive intervention in Angola in 1975, over 2,00o Cuban troops had served in various parts of Africa in the 196os. U.S. diplomats and intelligence analysts were largely unaware of these interventions. By comparison, only 40 Cubans fought in Latin America during the 1960s. This included Che Guevara and his ill-fated mission to Bolivia in 1967. Throughout the 196os, U.S. officials exaggerated Cuban activities in the Western Hemisphere, even as the United States repeatedly attacked Cuba, destabilized governments in Brazil and British Guiana, and invaded the Dominican Republic.

Gleijeses argues that Cuba took the initiative in Africa in the 196os, without the support or approval of the Soviet Union, motivated by both self-preservation and idealism. Cuban leaders wanted to relieve the U.S. pressure on them by creating, in Guevara's words, "two, three ... many Vietnams." After 
the dangerous Cuban Missile Crisis in 1962, the Soviet Union forbade Cuba from meddling in Latin America. Soviet leaders exploded, for example, when they learned that Guevara had clandestinely slipped into Bolivia. By the mid1970s, revolutionary idealism motivated the Cuban mission in Angola. Cuba displayed agency and enterprise when it sent 36,00o troops in 1975 and then reinforced that troop level to 55,000 in 1987-88 for the final push against South African troops. Cuban military leaders quarreled with Soviet military leaders over strategies and tactics. Cubans favored small-scale attacks in the difficult Angolan terrain, reasoning that the Soviets were too wedded to military tactics designed for the plains of Central Europe. Gleijeses concedes that the Cubans were dependent on Soviet military largesse, with the Soviets shipping over US\$ six billion in military equipment to Angola. Nonetheless, he argues that Soviet leaders, like Mikhail Gorbachev, were forced to accept the Cuban fait accompli.

Whether Cuba fundamentally altered the geopolitical order in southern Africa is not within the competence of this reviewer, whose specialty is interAmerican relations. Reviewers who have familiarity with the history and culture of southern Africa have criticized Gleijeses for simplifying the diplomatic objectives of South African leaders and exaggerating the Cuban role in South Africa's political evolution. Gleijeses has responded that his examination of South African archives led him to emphasize Cuba's military role. ${ }^{1} \mathrm{He}$ also noted that Nelson Mandela, who traveled to Cuba in 1991 to thank Cubans, repeatedly pointed to Cuba's vital military contributions and its "selflessness" in its relations with Africa (p. 526).

The enthusiasm that Gleijeses displayed for Cuban policy is implicitly challenged by Hatzky. The heart of her story lies in the sophisticated interviews that she conducted. She points to a marked contrast in her interviews with elites, like Jorge Risquet Valdés, and "ordinary" Cubans and Angolans. Cuban security officials wanted to protect the Cuban teachers who lived in a war zone, but they also wanted to monitor their thoughts and actions. They also demanded that Cuban teachers avoid sex among themselves and with Angolans in order to serve as exemplary role models for Angolans and avoid contracting sexually transmitted diseases. The "no-sex" rule was honored largely in the breach, for the teachers were young and often lonely. Cuban teachers also declined to learn Portuguese, assuming that Angolan students would understand their

1 See the forum on Visions of Freedom by seven scholars of southern Africa and the response by Gleijeses in H-Diplo Roundtable Review XV (July 14, 2014), 1-34. Stable URL: http://h-diplo .org/roundtables/PDF/Roundtable-XV-41.pdf. 
Spanish. At best, they tried instructing in portuñol, hybrid Spanish-Portuguese. ${ }^{2}$ Not surprisingly, Angolan teachers and students perceived such attitudes as "patronizing" (p. 198).

Hatzky also attacked the official memory of Cuba's celebrated history in Angola. Her interview subjects displayed symptoms of post-traumatic stress disorder (PTSD). But they are not permitted to discuss publicly the scenes of horrific war casualties and appalling poverty that they witnessed. Unhappy and frightened, Cuban teachers often disparaged their hosts in official reports, judging Angolans as undisciplined and lacking a work ethic, and denouncing them for cultural and social backwardness, for example citing an Angolan woman who "thought nothing of parading around with naked breasts, particularly in rural areas" (p. 258). As such, Cuban teachers imposed "civilizatory" habits upon their Angolan students in terms of personal conduct and hygiene (p. 241).

What distinguishes Hatzky's analysis from that of Gleijeses is that she extends her thinking beyond the 1991 withdrawal of Cuban troops and teachers. Cuban teachers, who by 1982 were covering nearly 80 percent of middle and higher education classes in Angola, strengthened the presence of the MPLA throughout the country. Gleijeses frequently makes the point that defeating UNITA and its tyrannical leader, Savimbi, was essential for Angola's future. But the MPLA, under the endless dictatorship of dos Santos, has transformed Angola into a harsh, corrupt country. With its oil, diamonds, and other mineral resources, Angola is a fortunate country. Luanda has the highest cost of living in the world, with one-bedroom apartments renting for \$10,000 a month. But Angola is ranked first in the world in the rate at which children die before the age of five, some 150,000 children a year. ${ }^{3}$ Perhaps the Cuban intervention was not such a "beautiful cause."

\section{Stephen G. Rabe}

Department of History, University of Texas at Dallas,

Richardson TX 75080, U.S.A.

rabe@utdallas.edu

2 For an analysis of Cuban doctors serving abroad that has findings similar to Hatzky's on Cuban teachers, see E. Cheasty Anderson, "Doctors Within Borders: Cuban Medical Diplomacy to Sandinista Nicaragua, 1979-1990," in Virginia Garrard-Burnett, Mark Atwood Lawrence, \& Julio E. Moreno (eds.), Beyond the Eagle's Shadow: New Histories of Latin America's Cold War (Albuquerque: University of New Mexico Press, 2013), pp. 200-25.

3 Nicolas Kristof, "Deadliest Country for Kids," New York Times, March 19, 2015, A27. 